\title{
MANAGEMENT OF LETTUCE BACTERIAL SOFT ROT DISEASE USING BIOTIC AND ABIOTIC AGENTS UNDER FIELD CONDITIONS
}

\author{
Mona A. Abbas*, Afaf, Z.A. El-Meneisy, Ebrahim, M.A.M.G. \\ and Abdel-Ghaffar N.Y. \\ Plant Pathology Dept., Fac. of Agric., Ain Shams Univ., P.O. Box 68, Hadayek Shoubra 11241, \\ Cairo, Egypt \\ *Corresponding author: mona_abas@agr.asu.edu.eg
}

Received 27 August, 2019

Accepted 4 September, 2019

\section{ABSTRACT}

The current investigation was planned to apply some biotic and abiotic treatments singlely and/or combined to control bacterial soft rot diseases of lettuce under field conditions. The application of resistance inducers (jasmonic acid and salicylic acid), antibiotics (norfloxacin and tetracycline) and bio-agents (isolates of $B$. subtilis and Ps. fluorescens) significantly reduced the disease severity as a single treatment compared to the control treatment. Obtained results indicated that resistance inducers appeared to be most effective against bacterial soft rot disease of lettuce compared with other treatments, while antibiotics were less effective at controlling the disease. However, the interaction between bio-agents as soil drench treatment, antibiotics, or resistance inducers as foliar treatment significantly reduced the severity of lettuce bacterial soft rot disease compared with the control treatment. Furthermore, interaction between disease severity was more reducted with interaction treatments between Ps. fluorescens isolate rather than interact with treatments between $B$. subtilis isolate and other treatments. However, interaction between isolate of $P$ s. fluorescens as bio-agent or norfloxacin or salicylic acid, were the most effective methods to control the disease compared with other treatments. Meanwhile, interaction between resistance inducers and antibiotics as foliar treatments were significantly reduced from severity of lettuce bacterial soft rot disease compared with the control. Disease severity was more reduced with application of interaction between norfloxacin and resistance inducers than interaction between tetracycline and resistance inducers. Meanwhile, the severity of the disease decreased more with the application of interaction between salicylic acid and antibiotics than the interaction between jasmonic acid and antibiotics. Generally, all combination treatments were more efficient than single treatments to manage the disease.

Keywords: Soft rot disease; Vegetable crops; Biotic agents and abiotic; Lettuce; Bactericides; Bioagents; Resistance inducers

\section{INTRODUCTION}

Vegetable plants are very necessary for human nutrition, as they supply our bodies with their needs from fibers, vitamins, and minerals. These important plants face great challenges, especially rots caused by plant pathogens. The pathogen causing soft rot disease attacks crops of almost all families including cucumbers, potatoes, carrots, lettuce, tomatoes, onions and ornamental plants like iris (Wood, 1998) because of its wide host range causing huge economic losses. The bacterium causes the disease to penetrate its host through wounds and natural openings such as hydathodes, lenticels and stomata. Then it secretes different enzymes that degrade plant cellwalls such as xylanase, cellulose, pectinmethylesterase (PME) and polygalacturonase (PG) causing the middle lamella to macerate and leading to cell death (Umunna and Austin, 2016).

Bacterial soft rot is commonly caused by species of gram-negative bacteria such as Erwinia, Pectobacterium and Pseudomonas(Elphinestone, 1997; Smith et al 1994 and Agrios, 2005). Bacterial soft rot disease, caused by Erwinia carotovora subsp. carotovora (Ecc) is one of the most bacterial destructive diseases of vegetables (Lakra, 2004). The pathogen exhibits a wide range of 
hosts, infecting a large number of vegetables, including cruciferous plants, cauliflowers and Chinese cabbage (Bhat et al 2010 and Kikumoto, 2000), and solanaceous vegetables such as potatoes and green peppers causing heavy economic losses (Liao, 2009 and Preombelon, 2002). The soft rot disease bacterium primarily enters plant tissues through injuries, which are often created by insect feeding. Soft rot disease is commonly aggravated by high temperatures and rainy season, which results in a fast rate of propagation in agricultural fields (Bhat et al 2010). Bacteria under the genus Pectobacterium spp. cause different diseases on a wide variety of crops worldwide. The bacterium has been isolated from dicotyledonous and monocotyledonous plants, water and soil and has also been reported to exist in association with many invertebrates (Glasner et al 2008). Pseudomonas marginalis or Ps. fluorescens can be attributed to soft rot diseases in vegetables. Also, other bacterial species i.e. Ps. cichorii, Ps. marginalis and Ps. viridiflare can cause soft rot and occur in the field, garden, greenhouse or after harvesting during transit, storage and marketing (Aremu and Babalola, 2015). The bacterium Xanthomonas campestris pv. campestris causes black rot disease and is considered the most serious disease of crucifers worldwide (Williams, 1980 and Popovic et al 2013). The disease can cause significant losses, especially in warm and humid environments (Williams, 1980).

Effective and environmentally safe methods for controlling these diseases are required to reduce the use of chemical pesticides. Biological control is one of the most promising approaches for controlling soil-borne plant diseases (Cui et al 2019; Fira et al 2018; Liu et al 2017). The control of pathogenic bacteria mainly depends on bacteriostatic agents such as hypochlorite, formaldehyde solutions and antibiotics (Bhat et al 2010). Microbial antagonists were applied to control soft rot pathogens and reduce the loss of vegetables (Dong et al 2004; Liao, 2009 and Zhao et al 2013). Chemicals available to control bacterial diseases have been limited, including antibiotics (Lalancette and McFarland, 2007) and many copper compounds (Carisse et al 2000 and Bull \& Koike, 2005). Bacterial leaf spot of lettuce was reduced by using resorcinol, two antioxidants and various sugar alcohol alone, and in combination with Tonos ${ }^{\circledR}$ SODF, under greenhouse and field conditions (Fayette et al 2016). One of the potential ways to activate the defense mechanisms of plants against bacterial disease pathogens is the induction of systemic acquired resistance (Shafikora and $\mathbf{Y u}$, 2015). Classic forms of systemic acquired resistance (SAR) can be caused by virulent, avirulent and non-pathogenic microorganisms or artificially with the help of chemicals, which are products of intermediate product of the immune response available for plants. These can be salicylic acid (SA), methyl salicylate, 2,6-dichloroisonicotinic acid (INA), jasmonic acid (JA), JA methyl, benzothiazole derivative, DL-B-aminobutric and oxalic acid (Plotnikora, 2009). The main objective of the present work was to control bacterial soft rot disease of lettuce using biotic and abiotic agents alone and/or combined under field conditions.

\section{MATERIALS AND METHODS}

\section{Field experiments}

Experiments were carried out on lettuce plants (60 days- old) under natural infection conditions, at Qaha region, Qalyubia governorate, Egypt. Treatments included the use of antibiotics, resistance inducers and bioagents single or combined, where the bioagents were used at $6 \times 10^{8} \mathrm{cfu} / \mathrm{ml}$ and the antibiotics at $75 \mathrm{ppm}$. A completely randomized block design was used in the experiment.

Antibiotics (tetracycline and norfloxacin) were applied as foliar applications. Also, resistance inducers (jasmonic acid $\left(\mathrm{C}_{12} \mathrm{H}_{18} \mathrm{O}_{3}\right)$ and salicylic acid (2- hydroxybenzoic acid, $\left.\mathrm{C}_{7} \mathrm{H}_{6} \mathrm{O}_{3}\right)$ ) were applied as foliar applications, while bioagents ( $B$. subtilis and $P$ s. fluorescens isolates) were applied as soil drench treatments, at a rate of $75 \mathrm{ppm}, 1.0 \mathrm{mM}$ and $10^{9}$ colony forming units $(\mathrm{cfu}) / \mathrm{ml}$, respectively. These factors were used singlely and combined to control bacterial soft rot disease of lettuce. Combination treatments were as follows: resistance inducers were spread on plant foliage's $48 \mathrm{~h}$ before application of antibiotics as foliar treatment, while bioagents were added around the plants as soil drench treatment 7 days before antibiotics and/or inducers factors such as foliar treatment. Lettuce plants were treated with control factors previously until run off and some plants were left without control factors such as control treatment. Each treatment consists of four rows, where each row is 1.5 $\mathrm{m}$ width $\times 7.0 \mathrm{~m}$ length and was replicated in three replicates (Carisse et al $\mathbf{2 0 0 0}$ and Fayette et al 2016). 

agents under field conditions

\section{Disease assessment}

Disease severity was estimated at 80 plants per treatment, where 20 plants per row were randomly selected after 10 days of the last treatment. Disease incidence was recorded at different times (7, 14 and 21 days) as average total lesions number per leaf, where three leaves were randomly selected from each plant and disease index (\%) was calculated according to rating scale from 0 to 5 , where 0 = no disease; 1 = a few single lesion; 2 = many single lesions; 3 = small patches of coalescent lesion; $4=$ moderate blighting of leaves and $5=$ extensive leaf blight (Bull, C.T. and Koike, 2005). The percentage of disease index (DI) was calculated by the following formula:

$$
\mathrm{DI}=\frac{\sum(R \times T)}{S \times N} \times 100
$$

Where: $T=$ Number of plants with the same disease severity scale $\mathrm{R}(0-5)$.

$\mathrm{N}=$ Total number of treated plants.

However, the percentage of disease control (PDC) was evaluated from the Disease index (\%) as follows:

$$
P D C=\frac{D I c k-D I t r}{D I c k} \times 100
$$

Where: $\mathrm{DI}_{\mathrm{ck}}=$ Disease index (\%) in control. $D I_{t r}=$ Disease index (\%) in treatment.

\section{Statistical analysis}

The data was statistically analyzed using ANOVA test and the value of LSD $(p=0.05)$ was calculated (Snedecor and Cochran, 1982).

\section{RESULTS}

\section{Field experiment}

Resistance inducers (jasmonic acid and salicylic acid), antibiotics (norfloxacin and tetracycline) and bio-agents (isolates of $B$. subtilis and Ps. fluorescens) were applied singlely to control bacterial soft rot disease of lettuce under natural infection conditions in Qaha region, Qalyubia governorate (Table 1). All treatments led to a decrease in the disease compared to control treatments. Salicylic acid and jasmonic acid as resistance inducers were the most effective against bacterial soft rot disease of lettuce compared to other treatments, where the percentage of disease control was 42.8 and $41.4 \%$, respectively. However, bio-agents i.e. $B$. subtilis and Ps. fluorescens isolates were moderately effective in reducing the disease, where percentage of disease control was 27.0 and $28.7 \%$, respectively, while antibiotics (norfloxacin and tetracycline) were less effective to control the disease, where the percentage of disease control was 21.6 and $20.4 \%$, respectively.

Results in Table (2) revealed that interaction between bio-agents as soil drench treatment and antibiotics as foliar treatment appeared effective against the severity of lettuce bacterial soft rot disease compared with the control treatment, where percentage of disease control was ranged from 28.2 to $30.7 \%$. Disease severity was more of a reduction with the application of interaction between Ps. fluorescens isolate and antibiotics rather than application of interaction between $B$. subtilis isolate and antibiotics, where percentages of disease control were $28.4-30.7 \%$ and $28.2-28.7 \%$, respectively. But, interaction between isolate of $P S$. fluorescens as bio-agent and norfloxacin as antibiotics showed the most efficacy to control the disease compared with other treatments, where the percentage of disease control was $30.7 \%$. Meanwhile, treatments of interaction between Ps. fluorescens isolate and tetracycline and interaction between $B$. subtilis isolate and norfloxacin or tetracycline were moderately effective in reducing the disease, where percentage of disease control was $28.4,28.7$ and $28.2 \%$, respectively.

Combinations between bio-agents (isolates of $B$. subtilis and Ps. fluorescens) such as soil drench treatment and resistance inducers (jasmonic acid and salicylic acid) as a foliar treatment were carried out to decrease severity of lettuce soft rot disease (Table, 3). Interaction treatments have reduced the disease compared with the control, where percentage of disease control ranged from 45.1 to $49.1 \%$. Interaction between Ps. fluorescens isolate as bio-agent and resistance inducers showed more efficacy against the disease than interaction between $B$. subtilis and resistance inducers, where percentage of disease control was $46.3-49.1 \%$ and $45.1-42.7 \%$, respectively. Also, interaction between salicylic acid as resistance inducers and bio-agents was more efficient to control the disease than interaction between jasmonic acid and bio-agents, where percentage of disease control was $47.7-49.1 \%$ and $45.1-46.3 \%$, respectively.

Results in the Table (4) showed that interaction between antibiotics (norfloxacin and tetracycline) as foliar treatment, resistance inducers (jasmonic acid and salicylic acid) as foliar treatment led to reduced severity of lettuce bacterial soft rot disease compared with the control, where percentage of disease control was ranged from 46.8 to $49.7 \%$. Disease severity was more reduced with 
Table 1. Effect of some resistance inducers, bactericides and bio agents on efficacy of disease control on lettuce plants, grown under natural infection conditions

\begin{tabular}{|c|c|c|c|c|c|c|c|c|c|}
\hline \multirow[t]{3}{*}{ Treatment } & \multicolumn{9}{|c|}{ Disease severity (\%) after } \\
\hline & \multicolumn{3}{|c|}{7 days } & \multicolumn{3}{|c|}{ 14day } & \multicolumn{3}{|c|}{21 day } \\
\hline & $A$ & $\mathrm{~B}$ & $\mathrm{C}$ & $A$ & $\mathrm{~B}$ & C & $A$ & $\mathrm{~B}$ & C \\
\hline Salicylic acid (1 Mm) & 8.9 & 17.1 & 17.0 & 11.0 & 18.3 & 28.0 & 15.1 & 19.9 & 42.8 \\
\hline Jasmonic acid (1 Mm) & 9.2 & 17.5 & 15.0 & 11.5 & 18.7 & 26.4 & 15.7 & 20.4 & 41.4 \\
\hline Tetracyclin (75 ppm) & 10.3 & 18.7 & 9.2 & 13.7 & 22.9 & 13.0 & 17.5 & 27.7 & 20.4 \\
\hline Norfloxacin (75 ppm) & 10.0 & 18.1 & 12.1 & 13.4 & 22.5 & 13.4 & 17.1 & 27.3 & 21.6 \\
\hline Bacillus subtilis $\left(1 \times 10^{8} \mathrm{cfu} / \mathrm{ml}\right)$ & 12.5 & 19.6 & 4.9 & 13.6 & 20.4 & 19.7 & 16.9 & 25.4 & 27.0 \\
\hline $\begin{array}{l}\text { Pseudomonas fluorescens } \\
\left(1 \times 10^{8} \mathrm{cfu} / \mathrm{ml}\right)\end{array}$ & 12.0 & 19.2 & 6.8 & 13.1 & 20.0 & 21.3 & 16.4 & 24.8 & 28.7 \\
\hline Control & 13.9 & 20.6 & 0.0 & 17.6 & 25.4 & 0.0 & 25.7 & 34.8 & 0.0 \\
\hline LSD at $5 \%$ & \multicolumn{3}{|c|}{ Treatment= 0.7} & \multicolumn{3}{|c|}{ Period $=1.0$} & \multicolumn{3}{|c|}{ Interaction $=1.6$} \\
\hline
\end{tabular}

$A=$ mean number of spots/leaf,$B=$ disease index $(\%), C=$ efficacy of disease control $(\%)$

Table 2. Effect of integration between bio agents as soil drench treatment and bactericides as folair spray on severity of bacterial soft rot disease on lettuce at different periode, under naturally infection conditions

\begin{tabular}{|c|c|c|c|c|c|c|c|c|c|c|}
\hline \multirow{3}{*}{$\begin{array}{c}\text { Bio agent } \\
\left(1 \times 10^{8} \mathrm{cfu} / \mathrm{ml}\right)\end{array}$} & \multirow{3}{*}{$\begin{array}{l}\text { Bactericide } \\
\text { (75 ppm) }\end{array}$} & \multicolumn{9}{|c|}{ Disease severity (\%) after } \\
\hline & & \multicolumn{3}{|c|}{7 days } & \multicolumn{3}{|c|}{ 14day } & \multicolumn{3}{|c|}{21 day } \\
\hline & & $\mathrm{A}$ & $\mathrm{B}$ & $\mathrm{C}$ & A & $\mathrm{B}$ & $\mathrm{C}$ & A & $\mathrm{B}$ & $\mathrm{C}$ \\
\hline \multirow{2}{*}{ Bacillus subtilis } & Norfloxacin & 9.3 & 17,4 & 15.5 & 10.0 & 20.1 & 20.9 & 11.3 & 24.8 & 28.7 \\
\hline & Tetracyclin & 9.8 & 18.0 & 12.6 & 10.4 & 21.3 & 16.1 & 11.9 & 25.0 & 28.2 \\
\hline \multirow{2}{*}{$\begin{array}{l}\text { Pseudomonas } \\
\text { fluorescens }\end{array}$} & Norfloxacin & 9.0 & 17.0 & 17.5 & 9.8 & 19.7 & 22.4 & 10.9 & 24.1 & 30.7 \\
\hline & Tetracyclin & 9.5 & 17.7 & 14.1 & 10.2 & 20.8 & 18.1 & 11.6 & 24.9 & 28.4 \\
\hline \multicolumn{2}{|c|}{ Control } & 13.9 & 20.6 & 0.0 & 17.6 & 25.4 & 0.0 & 25.7 & 34.8 & 0.0 \\
\hline \multicolumn{2}{|c|}{ LSD at $5 \%$} & \multicolumn{3}{|c|}{ Treatment= 0.6} & \multicolumn{3}{|c|}{ Period $=1.2$} & \multicolumn{3}{|c|}{ Interaction= 2} \\
\hline
\end{tabular}

$\mathrm{A}=$ mean number of spots/leaf, $\mathrm{B}=$ disease index $(\%), \mathrm{C}=$ efficacy of disease control $(\%)$

Table 3. Effect of integration between bio agents as soil drench treatment and resistance inducers as foliar spray on severity of lettuce bacterial soft rot disease, at different periods, under naturally infection condition

\begin{tabular}{|c|c|c|c|c|c|c|c|c|c|c|}
\hline \multirow{3}{*}{$\begin{array}{c}\text { Bio agent } \\
\left(1 \times 10^{8} \mathrm{cfu} / \mathrm{ml}\right)\end{array}$} & \multirow{3}{*}{$\begin{array}{c}\text { Resistance } \\
\text { induces }(1 \mathrm{Mm})\end{array}$} & \multicolumn{9}{|c|}{ Disease severity (\%) after } \\
\hline & & \multicolumn{3}{|c|}{7 days } & \multicolumn{3}{|c|}{ 14day } & \multicolumn{3}{|c|}{21 day } \\
\hline & & A & $\mathrm{B}$ & C & A & $\mathrm{B}$ & C & A & $\mathrm{B}$ & $\mathrm{C}$ \\
\hline \multirow{2}{*}{ Bacillus subtilis } & Jasmonic acid & 9.4 & 17.1 & 17.0 & 10.6 & 17.9 & 36.4 & 13.4 & 19.1 & 45.1 \\
\hline & Salicylic acid & 8.7 & 16.2 & 21.4 & 9.8 & 17.1 & 32.7 & 12.6 & 18.2 & 47.7 \\
\hline \multirow{2}{*}{$\begin{array}{c}\text { Pseudomonas } \\
\text { fluorescens }\end{array}$} & Jasmonic acid & 9.0 & 16.6 & 19.4 & 10.3 & 17.5 & 31.1 & 13.0 & 18.7 & 46.3 \\
\hline & Salicylic acid & 8.2 & 15.9 & 22.8 & 9.4 & 16.7 & 34.3 & 12.0 & 17.7 & 49.1 \\
\hline \multicolumn{2}{|c|}{ Control } & 13.9 & 20.6 & 0.0 & 17.6 & 25.4 & 0.0 & 25.7 & 34.8 & 0.0 \\
\hline \multicolumn{2}{|c|}{ LSD at $5 \%$} & \multicolumn{6}{|c|}{ Treatment=0.9, } & \multicolumn{3}{|c|}{ Interaction=1.9 } \\
\hline
\end{tabular}

$\mathrm{A}=$ mean number of spots/leaf, $\mathrm{B}=$ disease index $(\%), \mathrm{C}=$ efficacy of disease control $(\%)$ 

agents under field conditions

Table 4. Effect of interaction between bactericides as foliar treatment and resistance inducers as foliar treatment on severity of lettuce bacterial soft rot disease, at different periods, under naturally infection condition

\begin{tabular}{|c|c|c|c|c|c|c|c|c|c|c|}
\hline \multirow{3}{*}{$\begin{array}{c}\text { Bactericide } \\
\text { (75 ppm) }\end{array}$} & \multirow{3}{*}{$\begin{array}{c}\text { Resistance } \\
\text { induces } \\
(1 \mathrm{Mm})\end{array}$} & \multicolumn{9}{|c|}{ Disease severity (\%) after } \\
\hline & & \multicolumn{3}{|c|}{7 days } & \multicolumn{3}{|c|}{ 14day } & \multicolumn{3}{|c|}{21 day } \\
\hline & & A & B & C & A & B & C & A & B & C \\
\hline \multirow[t]{2}{*}{ Norfloxacin } & $\begin{array}{l}\text { Jasmonic } \\
\text { acid }\end{array}$ & 8.6 & 16.9 & 18.0 & 9.7 & 17.8 & 29.9 & 12.6 & 18.5 & 46.8 \\
\hline & Salicylic acid & 8.4 & 16.5 & 19.9 & 9.4 & 17.4 & 31.5 & 12.1 & 18.1 & 48.0 \\
\hline \multirow{2}{*}{ Tetracyclin } & $\begin{array}{l}\text { Jasmonic } \\
\text { acid }\end{array}$ & 8.4 & 16.4 & 20.4 & 9.3 & 17.2 & 32.3 & 11.9 & 17.9 & 48.6 \\
\hline & Salicylic acid & 8.1 & 16.1 & 21.8 & 9.0 & 16.9 & 33.5 & 11.6 & 17.5 & 49.7 \\
\hline \multicolumn{2}{|c|}{ Control } & 13.9 & 20.6 & 0.0 & 17.6 & 25.4 & 0.0 & 25.7 & 34.8 & 0.0 \\
\hline \multicolumn{2}{|c|}{ LSD at $5 \%$} & \multicolumn{3}{|c|}{ Treatment $=0.5}$, & \multicolumn{3}{|c|}{ Period=1.1, } & \multicolumn{3}{|c|}{ Interaction $=1.7$} \\
\hline
\end{tabular}

$\mathrm{A}=$ mean number of spots/leaf, $\mathrm{B}=$ disease index $(\%), \mathrm{C}=$ efficacy of disease control $(\%)$

the application of interaction between norfloxacin and resistance inducers than the interaction between tetracycline and resistance inducers, where percentage of disease control was $48.6-49.7 \%$ and $46.8-48.0 \%$, respectively. Interaction between salicylic acid and antibiotics was more effective than interaction between jasmonic acid and antibiotics against the disease, where percentage of disease control was $48.0-49.7 \%$ and $46.8-486 \%$, respectively.

\section{DISCUSSION}

Application of antibiotics i.e. norflaxcin and tetracycline, resistance inducers i.e. jasmonic acid and salicylic acid as foliar treatment and bio-agent i.e. isolates of B. subtilis and Ps. fluoresces as soil drench treatments as single treatments led to decreased severity of lettuce soft rot disease compared to control treatment, under natural infection conditions. Norflaxcin, salicylic acid and Ps. fluoresces isolate were the most effective in controlling the disease compared to other treatments. Interaction between antibiotics and bio-agents or resistance inducers significantly reduced the severity of the disease and interaction between bio-agents and resistance inducers was moderately effective to decrease disease severity. Interaction between norflaxcin as antibiotic and Ps. fluoresces isolate as bio-agent or salicylic acid as a resistance inducer were the most effective on disease severity compared to other treatments, but interactions between $B$. subtilis isolate as bio-agent and jasmonic acid as resistance inducers were less effective compared to other treatments. In addition, interaction treatments were more effective in disease severity than single treatments. Meuwly et al (1995) showed that SA is such an important factor in the signal transduction pathway causing systemic acquired resistance (SAR) to be synthesized from benzoic acid and phenylalanine (phe). Palva et al (1994) suggested that three are possible mechanisms for salicylic acid capability to induce resistance to some pathogenic bacteria. There are (1) Salicylic acid that could directly affect bacteria as a chelating agent, (2) Salicylic acid could act as an inducer of plant defense compounds such as pathogenesis-related (PR) proteins and (3) The inhibition could be a combination of both effects. The effect of salicylic acid (SA) or its derivatives on inducing resistance in plants against pathogens was reported by Malamy and Klessing (1992) who stated that the effect of SA was not caused by direct action on the growth of pathogens, but the effect of SA application was rather a consequence of induction of plant defense response. Many biochemical and soil changes occur during ISR i.e. pathogenesis-related (PR) proteins. Acidic PRproteins, including acidic chitinase and $\beta 1,3-$ glucanase are secreted in intercellular spaces, where they would be en-counted and /or bacterial pathogens, at an early stage of infection process. Basic $\beta$ 1,3-glucanase and chitinase accumulated in the vacuole may interact with pathogens at a later stage of infection during host cell deterioration (Ye et al 1995 and Kuc, 1995). 
However, SA has been established as a putative signal molecule that induces plant defense and systemic acquired resistance (SAR). Abiotic and biotic agents lead to the synthesis and accumulation of phytoalexins. The specificity of phytoalexin may be due to the regulation of the magnitude and rapidity of their accumulation and synthesis as this stay under genetic control of pathogen and host. As with phytoalexins suggested defense compounds produced by a given plant (lignin, phenolic, cross-linked cell wall polymers, hydroxyproline rich glycoproteins, callose, chitinase, thionins, B 1,3glucanase and peroxidases-related proteins) can be produced equally well be susceptible and resistance cultivars giving the proper conditions for elicitation (Wilson and Bachman, 1999). Glick, (2015).

Induced systemic resistance (ISR) is based on plant defense mechanisms that are activated by inducing agents such as PGPR (Klopper et al 1992) or ISR once expressed activity multiple potential defense mechanisms increasing in activity of defense enzymes and pathogenesis-related (PR) proteins (Lawton \& Lamb, 1987 and Strobel et al 1996) and phytoalexins (Kuc and Rush, 1985; Ongena et al 2000 and Jeun et al 2004). Plant growth-promoting bacteria (PGPB) could affect the growth of the plant either directly or indirectly. Glick (1995) reported that direct promotion of plant growth occurred either by (1) The PGBR eases the absorbance of minerals from the environment such as iron, phosphorus and nitrogen or (2) controls the growth of the plant by regulating or providing different plant hormones such as ethylene, cytokinin or auxin. Indirect stimulation of the growth of the plant by PGBR happens when a bacterium prevents or limits the injury to plant cells is caused by other plant pathogenic microorganisms including nematodes fungi and bacteria. So many common mechanisms are available for how PGBR indirectly promotes the growth of the plant involving the secretion of cell wall-degrading enzymes antibiotics, decreasing the levels of ethylene in the plants, induced systemic resistance, lowering the amount of available iron to pathogens and the synthesis of pathogen-inhibiting volatile compounds Plant growth-promoting rhizobacteria (PGPR) are root colonizing beneficial bacteria and the beneficial effects include biological control and growth promotion (Choudhary et al 2007; Conrath, 2006; Weller, 1988). Control of a wide spectrum of pathogens was studied by the application of antagonists largely remains an unfulfilled goal for biological control. There are three main approach- es to achieve this goal: (1) Modify the genetics of the bio-control agent to add mechanisms of disease suppression that are operable against more than the pathogen; (2) Alter the environment microflora and (3) Develop strain mixtures with superior bio-control activity (Janisiewicz, 1988). The induction of plant resistance is considered as one of the methods of reducing plant bacterial diseases. Induced resistance (IR) in plants has been studied in different plant-pathogen-interactions as a general phenomenon. Plants could be stimulated to improve their defence against infection by pathogens using various abiotic and biotic inducers (Walters et al 2005).

\section{REFERENCES}

Agrios G.N. 2005. Plant pathology, $4^{\text {th }}$ ed. Academic, London, pp. 25-37.

Aremu B.R. and Babalola O.O. 2015. Classification and taxonomy of vegetable macergens. Frontiers in Microbiology 6, 1-11.

Bhat K.A., Masoodi S.D., Bhat N.A., Ahmad M., Zargars M.Y., Mir S.A. and Bhat M.A. 2010. Studies on the effect of temperature on the development of soft rot of cabbage caused by Erwinia carotovora subsp. carotovora. J. of Phytopathology pp. 64-67.

Bull C.T. and Koike S.T. 2005. Evaluating the efficacy of commercial products for management of bacterial leaf spot on lettuce. Plant Health Progress, 10, 33-37.

Carisse O., Ouimet A., Toussaint V. and Philion V. 2000. Evaluation of the effect of seed treatments, bactericides and cultivars on bacterial leaf spot of lettuce caused by Xanthomonas campestris pv. vitians. Plant Disease, 84, 295299.

Choudhary D.K., Prakash A. and Johri B.N., 2007. Induced systemic resistance (ISR) in plants: mechanism of action. Indian J. Microbiol. 47, 289-297.

Conrath U. 2006. Systemic acquired resistance. Plant Signal. Behav. 1, 179-184.

Cui W., He, Pengjie, Munir S., He, Pengbo, He, Y., Li X., Yang L., Wang B., Wu Y. and He Pengfei 2019. Biocontrol of soft rot of Chinese cabbage using an endophytic bacterial strain. Front. Microbiol. 10 p.

Dong Y.H., Zhang X.F., Xu J.L. and Zhang L.H. 2004. Insecticidal Bacillus thuringiensis silences Erwinia carotovora virulence by a new form of microbial antagonism, singal interference. Applied and Environmental Microbiology 70, 954-960. 

agents under field conditions

Elphinestone J.G. 1997. Soft rot and black leg of potato. Technical Informational Bulletin 1, 18.

Fayette J., Roberts P.D., Jones J.B., Pernezny Y.L. and Raid R.L. 2016. Organic compounds increase the efficacy of famoxadone+cymoxanil in the control of bacterial leaf spot of lettuce. Crop Protection 89, 47-50.

Fira D., Dimkić I., Berić T., Lozo J. and Stanković S. 2018. Biological control of plant pathogens by Bacillus species. J. Biotechnol. 285, 44-55.

Glasner J.D., Marquez-Villavicencio M., Kim H.S., Jahn C.E., Ma B. and Biehi B.S. 2008. Niche-specificity and the variable fraction of the pectobacterium pan-genome. Molecular PlantMicrobe Interactions, 21, 1549-1560.

Glick B.R. 1995. The enhancement of plant growth by free-living bacteria. Canadian. Journal of Microbiology 41, 109-117.

Glick B.R. 2015. Beneficial Plant-Bacteria Interaction. Springer, Heidelberg, 243 p.

Janisiewicz W.J. 1988. Bio-control of postharvest diseases of apples with antagonist mixtures. Phytopayhology, 78, 194-198.

Jeun Y.C., Pack K.S., Kim C.H., Fowler W.D. and Kloepper J.W. 2004. Cytological observation of cucumber plants during induced resistance elicited by rhizobacteria. Biological Control, 29, 34-42.

Kikumoto T. 2000. Ecology and biocontrol of soft rot of Chinese cabbage. J. General Plant Pathology 66, 275-277.

Kloepper J.W., Tuzun S.D. and Kuc J. 1992. Proposed definitions related to induced disease resistance. Biocontrol Science Technology 2, 349-351.

Kuc J. 1995. Induction Systemic Resistance, An Overview. pp. 169-175. Kluwer Academic Publishers, Netherlands.

Kuc J. and Rush J.S. 1985. Phytoalexins. Arch. Biochem. Biophys., 236, 455-472.

Lakra B.S. 2004. Integrated approach for the management of soft rot (Pectobacterium carotovorum subsp. carotovorum) of radish seed crop. Haryana J. of Agronomy 20, 128-129.

Lalancette N. and McFarland K.A. 2007. Phytotoxicity of copper-based bactericides to peach and nectarine. Plant Disease 91, 1122-1130.

Lawton M.A and Lamb C.J. 1987. Transcriptional activation of plant defense genes by fungal elicitor, wounding and infection. Molecular Cell Biolology 7, 335-341.
Liao C.H. 2009. Control of foodborne pathogens and soft rot bacteria on bell pepper by three strains of bacterial antagonists. J. of Food Protection 72, 85-92.

Liu K., Newman M., McInroy J.A., Hu C.H. and Kloepper J.W. 2017. Selection and assessment of plant growth-promoting rhizobacteria for biological control of multiple plant diseases. Phytopathology 107, 928-936.

Malamy J. and Klessing D.F. 1992. Salicylic acid and plant disease resistance. Plant J. 2, 643645.

Meuwly P., Molders W., Buchala A. and Metraux J.P. 1995. Local and systemic biosynthesis of salicylic acid in infected cucumber plants. Plant Physiology 109, 1107-1114.

Ongena M., Daayf F., Jacques P., Thonart P., Benhamou N., Paulitz T.C. and Belange P.R. 2000. Systemic induction of phytoalexins in cucumber in response to treatments with fluorescent pseudomonads. Plant Pathology 49, 523-530.

Palva T.K., Holmstrom K.O., Heino P. and Palva E.T. 1994. Induction of plant defense response by bacteria as plant causal organism. Molecular Plant Microbe. Interaction 6, 190-196.

Plotnikora L.Y. 2009. Effect of benzothiadiazole, an inducer of systemic acquired resistance on the pathogenensis of wheat brown rust. Russian J. of Plant Physiology 56, 517-520.

Shafikora T.N. and Yu V. 2015. Molccular-genetic aspects of plant immunity to phytopathogenic bacteria and fungi. Plant Physiology 62, 571585.

Smith A.R.W., Zamze S.E. and Hignett R.C. 1994. Morphology and hydrolytic activity of $A 7$, a typing phage of Pseudomonas syringae pv. Morsprunorum. Microbiology 140, 905-913.

Snedecor G.W. and Cochran W.G. 1982. Statistical Methods. 7th Ed., lowa State Univ., Press, Towa, $511 \mathrm{p}$.

Strobel N.E., Ji C., Goolana S., Kuc J. and He S.Y. 1996. Induction of systemic acquired resistance in cucumber by Pseudomonas syrinage pv. syrinage 61 Hrpzpss protein. Plant J. 9, 431-439.

Umunna O.E. and Austin A.A. 2016. An overview of characterization and identification of soft rot bacterium Erwinia in some vegetable crops. Green J. of Biology Sci., 6, 46-55.

Walters D., Walsh D., Newton A. and Lyon G. 2005. Induced resistance for plant disease control: maximizing the efficacy of resistance elicitors. Phytopathology, 95, 1368-1373. 
Weller D.M. (988. Biological control of soil borne plant pathogens in the rhizosphere with bacteria. Annual Review Phytoathology 26, 379407.

Williams P.H. 1980. Black rot: A continuing threat to world crucifers. Plant Disease 64, 736-742.

Wilson M. and Bachman A. 1999. Biological control of plant pathogens. In: Handbook of pest Management. pp. 309-335 (Ruberson J.R., ed.). Marcel Dekker, Inc., New York.

Wood M. 1998. Ubi7-new tool for potato breeding. Agric. Research 1, 12-13.
Ye X.C., Strobel N. and Kuc J. 1995. Induce systemic resistance (ISR), activation of natural defense mechanisms for disease control as part of integrated pest management (IPM). In: Novel Approaches to Integrated Pest Management. pp. 95-113. (Kuc J., ed.), Plenum Press, New York.

Zhao Y.C., Li P.X., Huang K.H., Wang Y.N., Hu H.L. and Sun Y. 2013. Control of postharvest soft rot caused by Erwinia carotovora of vegetables by a strain of Bacillus amyloliquefaciens and its potential modes of action. World $\mathbf{J}$. of Micro. and Biotech., 29, 411-420. 


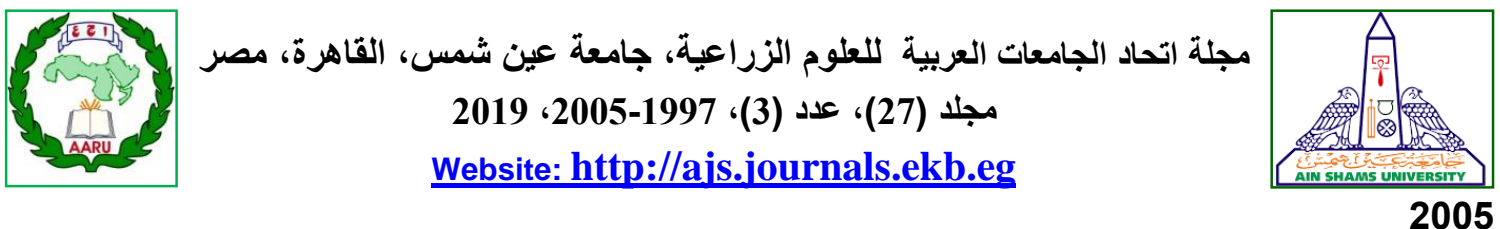

السيطرة على مرض العفن الطرى البكتيرى فى الخس مستخدما عوامل حيوية وغير حيوية تحت ظروف الطيرف الحقل

[160]

\author{
منى أحمد عباس" - عفاف زين العابدين المنيسي - محمد أحمد محمد جابر إبراهيم - \\ ناجى يسين عبد الغفار \\ قسم امراض النبات - كلية الزراعة - جامعة عين شمس - ص.ب 68 6ـ حدائق شبرا 11241 - القاهرة - مصر
}

*Corresponding author: mona_abas@agr.asu.edu.eg

Received 27 August, 2019

Accepted 4 September, 2019

والمعاملات الأخرى من معاملة التداخل بين بكتيريا B. subtilis عزل Ps. fluorescens كعامل حيوي وكل sن

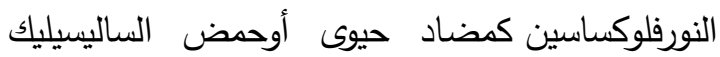
كعامل حث الأكثر فعالية للسيطرة على المرض ماد مقارنة

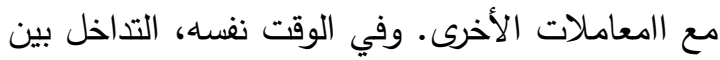

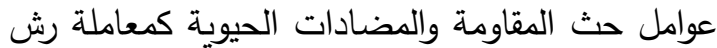

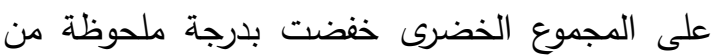

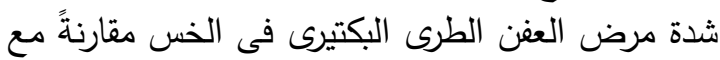

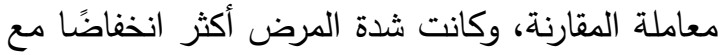

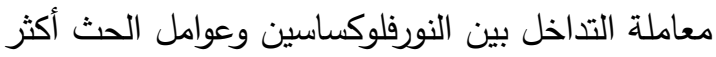

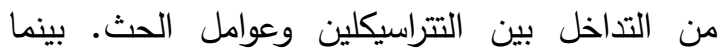

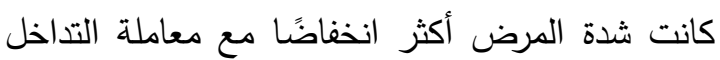

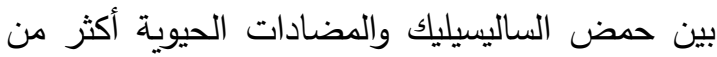
معاملة حض الجسمونيك و والمضادات الحين الحيوية. عموما، كانت معاملات التداخلات الأكثر فعالية من الجناتئ المعاملات الفردية لمكافحة المرض.

الكلمات الدالة: مرض العفن الطري البكتيري، عوامل

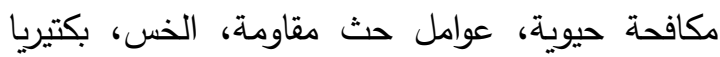
العفن الطرى، محاصيل الخضر الورقية، مضادات حيوية

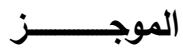

تعتير أمراض الأعفان الطرية البكتيرية في

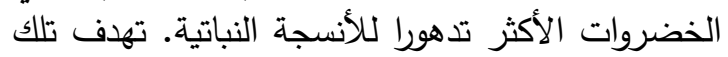

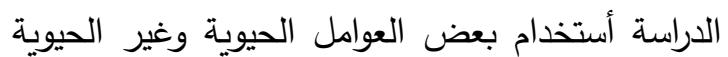

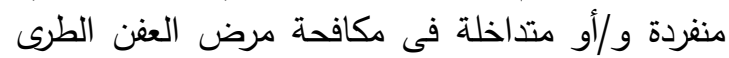
البكتيرى في الخس تحت ظتراو ظتروف الحقل (الأصابة

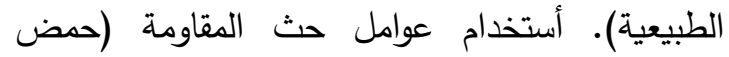
الجسمنك وحمض الساليسيليك)، والمضادات المات الحيوية

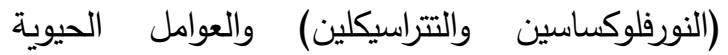

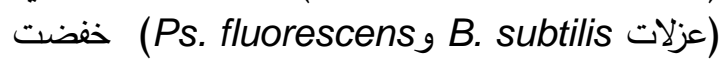

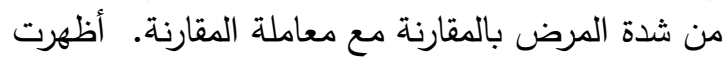

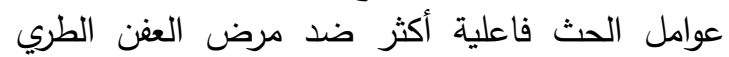

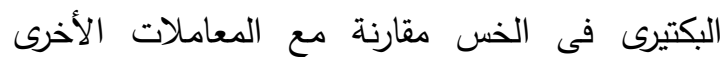

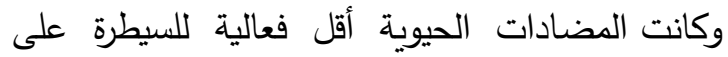

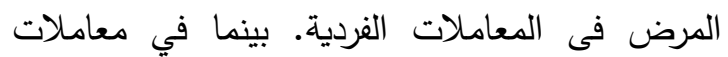
التداخل، كان التداخل بين العوامل الحيوية كمعاملة

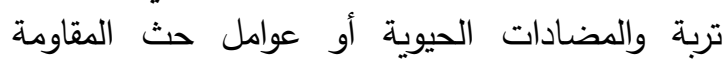

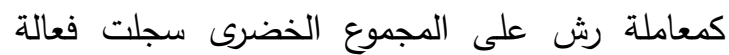

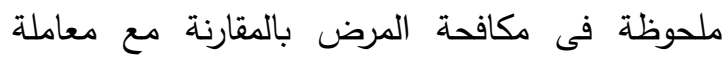
المقارنة وشدة المرض كانت أكثر انخفاض بمعاملة

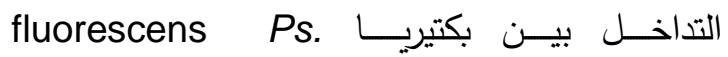

